\title{
Islam and Abortion: The Diversity of Discourses and Practices
}

\author{
Leila Hessini"
}

\begin{abstract}
1 Introduction
One in four world citizens is Muslim and 57 countries are official members of the Organisation of the Islamic Conference (OIC). ${ }^{1}$ Muslims comprise close to half of all Africans, one-fourth of Asians and growing numbers of Europeans and Americans, and represent great variation across racial, ethnic, linguistic and geographic lines. While all Muslims share certain core beliefs, official and practised Islam manifests itself in different ways as it intersects with local cultures, traditions, histories and politics.
\end{abstract}

The diversity found across the Muslim world is apparent in different countries' abortion laws and practices. Tunisia, for example, reformed its abortion law before France and the USA; services are provided free through the public healthcare system and pregnancy termination is socially accepted. While it is true that legal restrictions on abortion exist throughout the Muslim world, most are not due to shari' $a^{2}$ - as some might believe - but to antiquated colonial texts which are the basis for abortion laws in the majority of countries.

Examples from the three most populated Muslim countries are particularly revealing of these differences. In Indonesia, the most populated Muslim country with one of the highest unsafe abortion rates, several non-governmental organisations (NGOs) have been working for years to influence a change in the law and have mobilised key Muslim groups in their efforts. Pregnancy terminations are so common in Pakistan that on average, each Pakistani woman will experience one abortion in her lifetime (Population Council 2004). Menstrual regulation which allows for early evacuation of uterine contents after a missed pregnancy - has been an integral part of Bangladesh's primary healthcare for close to 30 years and as such, Bangladesh has one of the world's most decentralised systems of pregnancy termination (Nashid and Olsson 2007).

The goal of this article is to elucidate examples of the variations in Muslim belief and practice related to abortion. I begin by providing examples of abortionrelated practices and policies in key Muslim countries. Given the increased use of religion in public policy decisions, positions of religious leaders are discussed, followed by examples of strategies to break the silence around abortion and ensure that women have access to safe abortions. This article ends with suggestions on future prospects for change.

\section{What are the abortion-related practices and policies in key Muslim countries?}

Contrary to the image often painted of a monolithic Islamic position on abortion, great diversity exists across Muslim countries in terms of pregnancy termination practices and policies.

The most recent estimates of induced abortions worldwide indicate that the countries with the highest rates are the Muslim countries of Central Asia. In Azerbaijan, women will have on average three abortions in their lifetime and abortions are extremely common in Tajikistan, Turkmenistan and Kazakhstan (Sedgh et al. 2007). In Indonesia and Pakistan - the two predominantly Muslim countries with the biggest populations - close to 5,400 and 2,500 pregnancy terminations occur, respectively, each day (Utomo et al. 2001; Population Council 2004). The first national survey of abortion in Pakistan reveals that there is one abortion for every five births, resulting in 890,000 abortions per every year (Population Council 2004). Research indicates that without Bangladesh's menstrual regulation programme tens of thousands of women would still seek to end their pregnancies and would be forced to undergo unsafe abortions (Nashid 
and Olsson 2007). In the Middle East and North Africa region, one in ten pregnancies ends in abortion (UNFPA 2006); in Iran alone, over 1,000 abortions occur every day. The country with the lowest abortion rate is the one with the most liberal abortion law: Tunisia. These findings corroborate global evidence that restrictive laws do not lead to fewer abortions and that conversely, more permissive laws do not result in more abortions (Sedgh et al. 2007).

The majority of abortions in Muslim countries are unsafe as laws are restrictive and abortions often take place in clandestine settings by a person lacking the necessary skills or in an environment lacking minimal medical standards, or both (WHO 2003). The distinction between unsafe and safe abortions is critical to understanding how lack of access to safe abortion services is an issue of discrimination that leads to social inequities, widespread illness and premature death. When services are pushed underground, women have to pay high prices to access abortions, services are often of a poor quality, and governments have no responsibility to provide them - all factors which serve to perpetuate and deepen discrimination and social inequities.

Thirteen countries around the world account for 67 per cent of all maternal deaths and five of these Afghanistan, Bangladesh, Indonesia, Nigeria and Pakistan - have large Muslim populations (WHO 2007). While on average 13 per cent of global maternal deaths are due to unsafe abortions, this figure is closer to 50 per cent in the Central Asian Muslim republics (Sedgh et al. 2007). Moreover, for every woman who dies due to an unsafe abortion, the World Health Organization (WHO) estimates that thousands more experience severe and lifelong reproductive morbidities. These include reproductive tract infections, chronic pelvic pain, pelvic inflammatory disease, incontinence, and infertility. Women's unnecessary deaths and suffering from unsafe abortions are entirely preventable since abortion - when performed by a skilled provider in a clean environment - is one of the safest medical procedures (WHO 2003).

High abortion rates reflect elevated levels of unwanted pregnancies. The reasons women in Muslim countries decide to terminate a pregnancy are manifold. In many countries, the desired family size has decreased dramatically over the past decades and women are having children at a later age and ending their childbearing years earlier. Morocco is perhaps the Muslim country that has experienced the most drastic fertility decline from 7.0 in 1962 to 2.5 in 2004 (Royaume du Maroc 2005). But the proportion of currently married women with unmet need for contraception is also very high, at 24 per cent in subSahara African Muslim countries and 16 per cent in the Middle East and North Africa region (Ross and Winfrey 2002). Women also choose to terminate pregnancies due to social and financial concerns (RRAAM 2007; Telquel 2006; Seif El-Dawla A et al. 1998). Unintended pregnancies may result from sexual violence, especially in countries experiencing occupation, war and conflict - such as Iraq, Palestine and the Sudan. Adolescents and young persons representing more than 30 per cent of the population in many Muslim countries - are at particular risk of unsafe sex and unwanted pregnancies and few government programmes exist for this age group (DeJong et al. 2005).

\section{Legal status of abortion}

All Muslim countries allow for abortions to save a woman's life, in some cases under the 'defence of necessity.' ${ }^{3}$ However, 47 per cent of OIC countries legally permit abortion only for this one indication; another 18 per cent allow for abortions in cases of physical and/or mental health, fetal abnormality and/or rape and incest, and 18 per cent permit abortions on request. Interviews with healthcare professionals indicate that life and health provisions are interpreted quite broadly in some countries; in others such as Bangladesh and Indonesia, menstrual regulation is regularly practised.

Progressive interpretations of Islam, coupled with a desire to lower maternal mortality rates, have resulted in laws allowing for early abortion on request in Tunisia and Turkey, ${ }^{4}$ which completely liberalised their laws in 1973 and 1982, respectively. In the past 30 years, 17 other $\mathrm{OIC}$ countries have amended their abortion, health laws, or criminal codes to increase the legal indications for abortion. These include: Algeria (1985), Benin (2003), Burkina Faso (1996), Chad (2002), Djbouti (1995), Guinea (2000), Guyana (1995), Indonesia (1992), Iran (1991), Kuwait (1981), Mali (2002), Mozambique (1981), Niger (2006), Pakistan (1990), Saudi Arabia (1990) Sudan (1993) and Togo (2007). ${ }^{5}$

The majority of these changes include expanding legal indications such as: rape/incest, fetal abnormalities, 


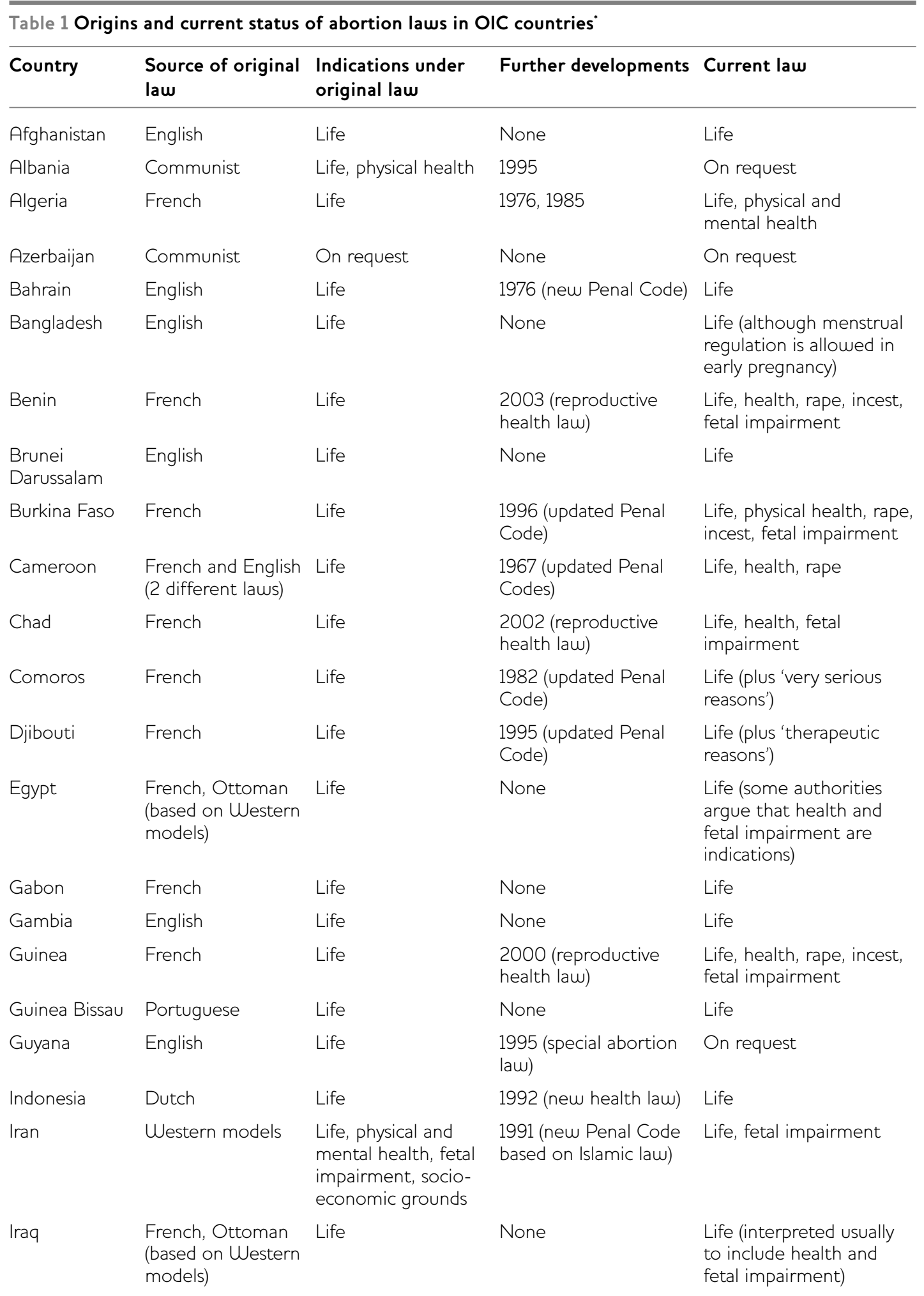




\begin{tabular}{|c|c|c|c|c|}
\hline Country & $\begin{array}{l}\text { Source of original } \\
\text { law }\end{array}$ & $\begin{array}{l}\text { Indications under } \\
\text { original law }\end{array}$ & Further developments & Current law \\
\hline Ivory Coast & French & Life & None & Life \\
\hline Jordan & $\begin{array}{l}\text { Ottoman (based on } \\
\text { Western models), } \\
\text { French }\end{array}$ & Life & 1971 (health law) & Life, health \\
\hline Kazakhstan & Communist & On request & None & On request \\
\hline Kuwait & Western models & Life & 1981 (special law) & $\begin{array}{l}\text { Life, health, fetal } \\
\text { impairment }\end{array}$ \\
\hline Kyrgyzstan & Communist & On request & None & On request \\
\hline Lebanon & $\begin{array}{l}\text { Western models, } \\
\text { Ottoman (based on } \\
\text { Western models) }\end{array}$ & Life & $\begin{array}{l}1969 \text { (Presidential } \\
\text { Decree) }\end{array}$ & Life \\
\hline Libya & Italian & Life & 1973 (health law) & Life \\
\hline Malaysia & English & Life & $\begin{array}{l}1969 \text { (amendment } \\
\text { of Penal Code) }\end{array}$ & $\begin{array}{l}\text { Life, physical and mental } \\
\text { health }\end{array}$ \\
\hline Maldives & $\begin{array}{l}\text { Unclear, probably } \\
\text { Islamic law }\end{array}$ & $\begin{array}{l}\text { Unclear, probably life, } \\
\text { fetal impairment }\end{array}$ & None & $\begin{array}{l}\text { Unclear, probably life, } \\
\text { fetal impairment }\end{array}$ \\
\hline Mali & French & Life & $\begin{array}{l}2002 \text { (reproductive } \\
\text { health law) }\end{array}$ & Life, rape, incest \\
\hline Mauritania & French & Life & None & Life \\
\hline Morocco & French & Life & $\begin{array}{l}1967 \text { (amendment of } \\
\text { Penal Code) }\end{array}$ & Life, health \\
\hline Mozambique & Portuguese & Life & $\begin{array}{l}1981 \text { (Ministry of Health } \\
\text { Decree interpreting } \\
\text { abortion law) }\end{array}$ & $\begin{array}{l}\text { Life, health, contraceptive } \\
\text { failure }\end{array}$ \\
\hline Niger & French & Life & $\begin{array}{l}2006 \text { (reproductive } \\
\text { health law) }\end{array}$ & $\begin{array}{l}\text { Life, health, fetal } \\
\text { impairment }\end{array}$ \\
\hline Nigeria & English & Life & None & Life \\
\hline Oman & $\begin{array}{l}\text { Western, Ottoman } \\
\text { (based on Western } \\
\text { models), Islamic law }\end{array}$ & Life & None & Life \\
\hline Pakistan & English & Life & $\begin{array}{l}1990 \text { (Islamic law } \\
\text { amendment to the } \\
\text { Penal Code }\end{array}$ & $\begin{array}{l}\text { Life, 'necessary } \\
\text { treatment' }\end{array}$ \\
\hline Palestine & $\begin{array}{l}\text { Western, Ottoman, } \\
\text { Egyptian, Jordanian }\end{array}$ & Life & Unclear & Life \\
\hline Qatar & $\begin{array}{l}\text { Ottoman (based on } \\
\text { Western models), } \\
\text { Western models }\end{array}$ & Life & $\begin{array}{l}1983 \text { (law on medical } \\
\text { professions) }\end{array}$ & $\begin{array}{l}\text { Life, health, fetal } \\
\text { impairment }\end{array}$ \\
\hline Saudi Arabia & $\begin{array}{l}\text { Islamic law } \\
\text { (uncodified) }\end{array}$ & Life & $\begin{array}{l}1990 \text { (Ministry of } \\
\text { Health Resolution law } \\
\text { based on Islamic law) }\end{array}$ & $\begin{array}{l}\text { Life, health, to } \\
\text { accomplish a legal } \\
\text { benefit or to prevent an } \\
\text { expected harm (not } \\
\text { socioeconomic) }\end{array}$ \\
\hline
\end{tabular}




\begin{tabular}{|c|c|c|c|c|}
\hline Country & $\begin{array}{l}\text { Source of original } \\
\text { law }\end{array}$ & $\begin{array}{l}\text { Indications under } \\
\text { original law }\end{array}$ & Further developments & Current law \\
\hline Senegal & French & Life & None & Life \\
\hline Sierra Leone & English & Life & None & Life \\
\hline Somalia & Italian & Life & None & Life \\
\hline Sudan & English & Life & $\begin{array}{l}1983 \text { (new Penal Code } \\
\text { based on Islamic law) }\end{array}$ & Life, rape, deceased fetus \\
\hline Suriname & Dutch & Life & None & Life \\
\hline Syria & $\begin{array}{l}\text { Western models, } \\
\text { Ottoman (based on } \\
\text { Western models) }\end{array}$ & Life & $\begin{array}{l}1970 \text { (law on medical } \\
\text { professions) }\end{array}$ & Life \\
\hline Tajikistan & Communist & On request & None & On request \\
\hline Togo & French & Life & $\begin{array}{l}2007 \text { (reproductive } \\
\text { health law) }\end{array}$ & $\begin{array}{l}\text { Life, health, rape, incest, } \\
\text { fetal impairment }\end{array}$ \\
\hline Tunisia & French & Life & $\begin{array}{l}1973 \text { (amendment to } \\
\text { the Penal Code) }\end{array}$ & On request \\
\hline Turkey & $\begin{array}{l}\text { Ottoman (based on } \\
\text { French models) }\end{array}$ & Life & $\begin{array}{l}1982 \text { (family planning } \\
\text { law) }\end{array}$ & On request \\
\hline Turkmenistan & Communist & On request & None & On request \\
\hline Uganda & English & Life & None & Life \\
\hline UAE & $\begin{array}{l}\text { Western models, } \\
\text { Ottoman (based on } \\
\text { Western models) }\end{array}$ & Life & $\begin{array}{l}1975 \text { (law on the } \\
\text { practice of human } \\
\text { medicine) }\end{array}$ & Life \\
\hline Uzbekistan & Communist & On request & None & On request \\
\hline Yemen & $\begin{array}{l}\text { Islamic law } \\
\text { (uncodified) }\end{array}$ & Life & $\begin{array}{l}1994 \text { (new Penal Code } \\
\text { based on Islamic law) }\end{array}$ & Life \\
\hline
\end{tabular}

* The indication of 'life' encompasses two types of laws. One kind specifically provides that an abortion is permitted to save the life of a pregnant woman. The other includes provisions found in criminal codes that allow a person to argue that he or she has preserved a greater good - for example saving a woman's health or life - by committing an illegal act. According to this principle, an abortion would be considered an act of necessity if it were performed to save the life of the pregnant woman. It would be thought of as the lesser of two evils. Indeed, most penal codes have provisions allowing the defence of necessity in general, although not with regard to any specific crime such as abortion. This table does not distinguish between the two kinds of laws except in cases when a later law actually specified that an abortion was allowed to save the life of a pregnant woman, whereas the earlier law was understood as allowing abortions in a case of necessity.

and/or mental and physical health, but do not go as far as acknowledging a woman's right to obtain a legal abortion upon request. Efforts have been prompted by governments' desires to implement their commitments made at the 1994 International Conference on Population and Development (ICPD), increased attention to sexual violence, rape and incest, use of prenatal testing and the ability to screen for fetal impairment, and broadening the definition of 'preserving women's health'. In the cases of Iran, Saudi Arabia, Sudan and Yemen, former laws were replaced with codes based on shari'a. Saudi Arabia's reformed law permits abortion in cases of threats to life, health, to accomplish a legal benefit or to prevent an expected harm, and is more permissive than its previous colonial legislation. 
Since all countries allow at least a life-saving provision, if not other indications, groups in some countries are working to ensure that the provisions in existing laws are implemented to the fullest extent. In Malaysia, where abortions are legal to save the pregnant woman's life or to protect her physical and mental health, a group of NGOs has launched a campaign that includes informing women of their legal rights and assuring that health professionals provide services to the extent of the law (RRAAM 2007).

\section{What are the positions of Muslim religious leaders?}

Analyses of medieval Arabic texts demonstrate that discussions about contraceptive practices in Islamic jurisprudence, medical journals, and popular literature were very common (Musallem 1983). The Prophet Mohammed practised coitus interruptus, or withdrawal, and encouraged others to do so as long as there was mutual consent. Medieval Muslim scholars debated the circumstances under which abortions were permissible in Islam. Discussions on the latter included an analysis of the pregnant women's circumstances, information on fetal gestational age and deliberations over whether more harm would be caused by continuing or by ending the pregnancy. It was generally accepted that maternal life carried precedence over that of the fetus at least until the fetus achieved the status of person, considered to be at the time of 'ensoulment' defined as occurring anywhere between 40, 90 or 120 days. Abortions after this time were prohibited unless there was 'just cause' - usually defined as saving a women's life or their health (Asman 2004). The lives of existing children were also considered more important than that of the fetus; breastfeeding women or mothers who could not afford another child were allowed to terminate a pregnancy. Some scholars argued that women should be allowed to terminate a pregnancy for socioeconomic reasons or due to a pregnant woman's desire to maintain her beauty (Musallem 1983).

In light of the increased introduction of population planning programmes, several meetings in the 1960s brought together muftis ${ }^{7}$ and health professionals to discuss Muslim positions on family planning. A panIslamic conference in Cairo in 1965 and another in Kuala Lumpur in 1969 approved the use of birth control for economic reasons, defined as the inability to support additional offspring. This was an important advance, as opponents of contraception and abortion had often pointed to Qur'anic passages stating that Allah will provide for all human beings in their arguments to oppose family planning and pregnancy termination. A subsequent international conference on Islam and family planning in 1971 concluded that Islam forbids abortion after the fourth month of pregnancy, unless the woman's life is in danger but allows for abortion under several circumstances in the first four months (IPPF 1974). In 1979, the Pakistan Demographic Policies and Implementation Research Center in Lahore published a guide of Fatwas ${ }^{8}$ by Eminent Muslim Scholars on population and family planning issues that recognises the diversity of opinions about the religious sanctioning of abortion in the first four months of pregnancy. A subsequent meeting of Asian and Middle Eastern experts and religious leaders called on governments to recognise unsafe abortion as a public health issue, review outdated abortion laws and provide women with more human treatment and better access to contraception (IPPF 1992).

In recent years, religious fatwa have been issued clarifying contemporary Muslim positions on abortion. In countries with high rates of consanguineous - or interfamily - marriages, debates have centred on whether women carrying impaired fetuses can terminate a pregnancy. After much discussion among religious leaders, a fatwa was issued in 1991 in Saudi Arabia allowing for abortion in the first 120 days after conception in the case of fetal abnormalities (Alkuraya and Kilani 2001). In Iran, the Grand Mufti Ayatollah Yusuf Saanei issued a fatwa in 2005 permitting abortions in cases of genetic disorder in the first trimester (Hamshari Daily 2005).

Rape is increasingly recognised by Muslim religious leaders as a legitimate reason for abortion. The Egyptian Grand Sheikh of al-Azhar, Muhammed Sayed Tantawi, issued a fatwa in 1998, stating that unmarried women who had been raped should have access to abortion (IURAW 1998). In 2004, he stated that abortion must be provided if the woman's life is in danger and he approved a draft bill that included rape as an indication. In Algeria, the Islamic Supreme Council issued a fatwa in 1998, stating that abortions were allowed in cases of rape, as rape was being used by religious extremists as a weapon of war (Chelala 1998). In contrast, after discussions about the rapes of Kuwaiti women by Iraqi soldiers during the first Gulf War, Kuwaiti muftis decided that rape did not justify the need for legal abortion (Asman 2004). Yet the arguments used by the Kuwaiti muftis - that life 
begins at conception and the innocent life of the fetus should be protected - have more in common with fundamentalist Christian views than Islamic jurisprudence.

While fatwa are increasingly being used in debates on abortion, they are not legally binding unless they are translated into law. Moreover, their impetus is not necessarily women's rights. In Egypt, the Grand Mufti argued that rape victims should have access to abortions and to reconstructive hymen surgery to preserve female marriageability and virginity (IURAW 1998). There is also debate over who can issue a fatwa and what occurs in cases of competing religious positions. For example, in Indonesia, a group of prominent Muslim scholars proposed that the abortion law be changed to include cases of rape and incest but this was rejected by the pro-government Indonesian Ulemas Council (Jakarta Post 2004). Moreover, the patriarchal tradition allows only men to serve as muftis. The issuing of fatawa has been criticised by some women's groups as an intrusion of religion into secular matters (Hessini 2007).

\section{What steps are being taken to tackle the} problem of unsafe abortions in Muslim countries? Different strategies are being used to modify abortion laws, influence religious debates and ensure women's access to safe abortion services. While an analysis of these strategies is beyond the scope of this article, three promising approaches -

documenting women's experiences with unwanted pregnancies and unsafe abortions, learning from model countries and advances in abortion techniques - are briefly discussed in the following section.

\subsection{Documenting women's experiences}

Ethnographic and anthropological studies in Muslim societies have documented the abortion experiences and perceptions of different groups of women in order to break the silence on sexuality and unwanted pregnancies and understand women's abortion related-needs. This is critical as religious and political debates on abortion are often detached from the realities of women's lives.

Studies on women's perceptions of abortion in Egypt and Morocco highlight the belief that induced abortions are a common occurrence that is deemed necessary and justified under certain conditions. While Islam is a strong presence in women's lives, several studies show that it does not necessarily govern the everyday reproductive and sexual choices of most of the women interviewed. Rather, women - whether trying to avoid unwanted sex or unwanted pregnancies - often rely on their belief in God's compassion rather than on the opinions of religious authorities (Seif El Dawla et al. 1998; Telquel 2006).

The needs and experiences of different groups of women have also been studied. While abortions may be socially-accepted for married women who have completed child-bearing, it may be more stigmatised for single women. Interviews with Indonesian and Moroccan women show that young and unmarried women are much more likely to experience shame and stigma from the abortion experience than their married counterparts (Bennett 2001; Telquel 2006). Healthcare professionals are often less willing to provide high-quality, non-judgemental services to single pregnant women and services are more expensive.

The role of women's social networks has also been researched as an important source of information for women seeking abortion services. Research in Bangladesh and Pakistan indicates that women rely on a network of individuals who provide information, transportation and resources when seeking to terminate a pregnancy and that these intermediaries can serve an important role in assuring that women have access to safe abortions (Population Council 2004; Nashid and Olsson 2007).

\subsection{Learning from model countries: the example of Tunisia}

Another approach has been to strengthen south-tosouth cooperation and learn from successful models of abortion care. Tunisia is known for its pioneering role linking the areas of women's status,

reproductive rights and abortion. It is unique in that it has adopted an approach that situates women's reproductive decision-making in the broader context of their overall rights and decision-making status. Following independence in 1956, Tunisia banned polygamy, gave women equal rights to divorce, and changed labour laws to promote women's integration into the market economy.

In 1973, Tunisia became the first Arab, African and Muslim country to completely liberalise its abortion law. Tunisia's legislation is notable as it allows for abortion on request for a broad range of socioeconomic factors in the first trimester; it does not require spousal consent and services are offered 
free of charge in government clinics. Tunisia is also one of a few countries to have established programmes that explicitly address young people's sexual and reproductive health, and the abortion rate is lower than all other Muslim, African or Arab countries.

In order to share Tunisia's experience, several study tours have been organised by the National Office for the Family and Population (Office National de la Famille et de la Population, ONFP) for health professionals from key African Muslim countries including Mauritania, Mali and Niger, as well as others.

\subsection{Advances in abortion technologies}

Women-centred abortion technologies are critical to advancing women's rights and autonomy. Medical advances have resulted in methods that are extremely safe and effective, that can be used by a variety of healthcare providers in both high and low resource settings, and directly by women. Medical abortion regimens using mifepristone and a prostaglandin, usually misoprostol, are being introduced in some Muslim countries such as Egypt, Turkey and Tunisia, to ensure that women have access to a variety of safer and women-controlled options. In Tunisia,

mifepristone has been approved and medical abortion is available in public clinics. Research indicates that this abortion method - and in particular its home use $^{9}-$ may be preferred by both unmarried and married Tunisian women due to reasons of confidentiality, privacy, convenience, reduced cost for transportation to the health facility and ability to avoid a surgical procedure (Blum et al. 2004)

\section{Conclusion}

It is clear from this article that there is no single Islamic or Muslim position on abortion. Instead there is great diversity in terms of Muslim discourse, state policies and individual decision-making related to pregnancy termination. While it is difficult to generalise across such diverse countries, this overview suggests that there is no apparent link between state religion, individual religiosity and abortion prevalence. Countries - such as Iran and Pakistan - which may seem the most 'Islamic' in that they follow shari'a have some of the highest abortion rates and Saudi Arabia's shari'ainspired law is more permissive than Morocco's colonial legislation. Another observation is that the parameters of the abortion debate, and the language used focuses on efforts to preserve women's life, health and societal cohesion, and as such differs substantially from the prolife and pro-fetus rhetoric that is prevalent in the USA.
Abortion debates, however, rarely include the perspectives and realities of those most affected by unwanted pregnancies: women. Moreover, in many Muslim countries today - as well as globally - culture and religion are increasingly being used to justify patriarchal practises. While current fatawa are limited in their backing for abortion, historical research shows that vibrant debates have existed across Islamic history and that support exists for women's right to sexual fulfilment, to manage their fertility and access abortion services when needed. Researchers and activists are producing historic and textual analysis of the diversity of approaches to women's sexual and reproductive rights in Muslim societies (llkkaracan 2000) and the relationship between normative Islam and reproductive health (SIS 1998) to counter conservative trends.

Grassroots efforts are also under way. In Indonesia women's groups are working through the pesantren (Muslim boarding schools) to study and overturn discriminatory interpretations of religious texts (Sciotino et al. 1996), and in Pakistan organisations work to promote community awareness and mobilisation around sexuality and the individual and collective impact of unwanted pregnancies and unsafe abortions (Aahung 2005). Other groups have translated women-centred reproductive and sexual knowledge into practice and are developing training courses on Islam, gender and reproductive rights (Muhammed et al. 2006).

Another strategy is to deconstruct the myth that men are the only ones who can interpret religious texts and hold religious positions. Research has highlighted the diverse leadership roles that women played at the origins of Islam and in various Muslim countries (Shaheed 2004). In Morocco, hundreds of women have been trained as mourshidat - Islamic scholars and spiritual guides.

While engaging with religion is one approach, some activists and scholars situate their efforts from a secular perspective and seek to link women's human rights, gender equality and access to safe and legal abortions. Many Muslim countries made positive developments in recognising unsafe abortion as a public health and human rights issue over the past decade. At the International Conference on Population and Development (ICPD), all OIC governments agreed that women who experienced unwanted pregnancies should have access to: 
(1) reliable information, (2) compassionate counselling, and (3) under circumstances where abortion is not against the law, safe abortion services (POPIN 1994). It has also been recognised that women are unable to benefit from their most basic, internationally recognised human rights without access to abortion services. These include: (a) the right to liberty, (b) the right to privacy, (c) the right to non-discrimination, (d) the right to equality, (e) the right to life, (f) the right to health and healthcare, $(\mathrm{g})$ the right to information, (h) the right to freedom of conscience and religion, (i) the right to benefits of scientific progress, (j) the right to be free of cruel, inhumane and degrading treatment, and $(k)$ the right to decide the number and spacing of one's children (de Bruyn 2002). Moreover, laws that criminalise abortion - a procedure sought by tens of millions of women, and only women, each year - constitute gender-based discrimination and are against the spirit of the Convention on the Elimination of All Forms of Discrimination (CEDAW), signed or ratified by the majority of Muslim countries (Hessini, forthcoming 2008).

These approaches are often used in tandem with groups working from within religions parameters. Ultimately, different strategies are necessary to ensure that all Muslim women are able to benefit from their most basic sexual and reproductive rights.

\section{Notes}

* We are grateful to the editor of Reproductive Health Matters for permission to reproduce one section of this article and to Reed Boland who produced the table of abortion laws.

1 The $\mathrm{OIC}$ is an inter-government body that serves to promote the interest of, and solidarity between Muslim countries. This article includes examples from OIC member states.

2 Islamic law.

3 A provision found in criminal codes that allows a person to argue that he or she has preserved a greater good - for example saving a woman's health or life - by committing an illegal act.

\section{References}

Aahung (2005) Aahung Final Report, Karachi: Aahung Alkuraya, F.S. and Kilani, R.A. (2001) 'Attitude of Saudi Families Affected with Hemoglobinopathies Towards Prenatal Screening and Abortion and the Influence of Religious Ruling', Prenatal Diagnosis 21: 448-51

Asman, O. (2004) 'Abortion in Islamic Countries: Legal and Religious Aspects', Medicine and Law 23: 73-89

Bennett, L.R. (2001) 'Single Women's Experiences of Premarital Pregnancy and Induced Abortion in Lombok, Eastern Indonesia', Reproductive Health Matters 9.17: 37-43

Blum, J.; Hajri, S. and Chélli, H. (2004) 'The Medical Abortion Experiences of Married and Unmarried Women in Tunis, Tunisia', Contraception 69.1: 63-9

Chelala, C. (1998) 'Algeria Abortion Controversy Highlights Rape of War Victims', Lancet 351: 1413
4 Tunisia is notable for being the first Muslim, African and Arab country to liberalise its law.

5 See Table 1 for an analysis of the origins and current status of abortion laws in OIC countries.

6 This section is inspired by a previous publication by the same author (Hessini 2007).

7 Scholars who interpret religious laws and texts.

8 A fatwa is a non-binding religious edict (the plural is fatawa or fatwas).

9 Home use of misoprostol has only been extensively studied in gestations of nine weeks and under, and has been found to be safe, effective and acceptable.

de Bruyn, Maria (2002) Human Rights, Unwanted Pregnancy and Abortion-related Care, Reference Information and Illustrative Cases, Chapel Hill: Ipas

DeJong, J.; Jawad, R. and Mortagy, I. (2005) 'The Sexual and Reproductive Health of Young People in the Arab Countries and Iran', Reproductive Health Matters 13.25: 45-9

Hamshari Daily, 'Iran: The Abortion Bill' (2005) 13 April

Hessini, L. (2007) 'Abortion and Islam: Policies and Practices in the Middle East and North Africa', Reproductive Health Matters 15.29: 1-10

Hessini, L. (forthcoming 2008) Achieving Gender Equality in Algeria, Morocco and Tunisia: Is the Ability to Safely Terminate a Pregnancy Important?, Arab Women's Center for Research and Training (CAWTHAR) and the Ford Foundation

Ilkkaracan, P. (ed.) (2000) Women and Sexuality in Muslim Societies, Istanbul: Women for Women's Human Rights 
IPPF (1992) Unsafe Abortion and Sexual Health in the Arab World, Damascus: International Planned Parenthood Foundation

IPPF (1974) Islam and Family Planning, London: International Planned Parenthood Foundation

IURAW (International Women's Rights Action Watch) (1998) The Women's Watch 12.1/2

Jarkarta Post (2004) 'Indonesia: Abortion Issue Sparks Variety of Reactions', 7 April

Muhammed, K.H.; Kodire, F.A.; Natsir, L.M. and Wahid, M. (2006) Dawrah Fiqh Concerning Women: A Manual for a Course on Islam and Gender, Jakarta: Fahmina Institute

Musallam, B.F. (1983) Sex and Society in Islam, Cambridge: Cambridge University Press

Nashid, T. and Olsson, P. (2007) 'Perceptions of Women About Menstrual Regulation Services: Qualitative Interviews from Selected Urban Areas of Dhaka', Health Population Nutrition 25.4: 392-8

POPIN (United Nations Population Information Network) (1994) Programme of Action of the International Conference on Population and Development (ICPD), Cairo, Egypt

Population Council (2004) Unwanted Pregnancy and Post-Abortion Complications in Pakistan: Findings from a National Study, Karachi: Population Council

Ross, J.A. and Winfrey, W.L. (2002) 'Unmet Need for Contraception in the Developing World and the Former Soviet Union: An Updated Estimate', International Family Planning Perspectives 28.3: 138-143

Royaume du Maroc (2005) Enquête sur la Population et La Sante Familiale [Survey on Population and Family Health], Ministère de la Sante, ORC Macro, Project PAPFAM

RRAAM (2007) Information Brief: Speaking Out on Malaysian Women's Access to Contraception and Abortion Services, Kuala Lumpur: Reproductive Rights Advocacy Alliance Malaysia
Sciortino, R.; Marcoes Natsir, L. and Mas'udi, M. (1996) 'Learning from Islam: Advocacy of Reproductive Rights in Indonesian Pesantren', Reproductive Health Matters 8: 86-96

Sedgh, G.; Henshaw, S.K.; Singh, S.; Bankole, A. and Drescher, J. (2007) 'Legal Abortion Worldwide: Incidence and Recent Trends', International Family Planning Perspectives 33.3: 106-116

Seif El-Dawla, A.; Hadi, A.A. and Wahab, N.A. (1998) 'Women's Wit Over Men's Trade-offs and Strategic Accommodations in Egyptian Women's Reproductive Lives', in R. Petchesky and K. Judd (eds), Negotiating Reproductive Rights, London: Zed Books

Shaheed, F. (2004) Great Ancestors: Women Asserting Rights in Muslim Contexts, Lahore: Women's Resource Center

SIS (1998) Islam, Reproductive Health and Women's Rights, Kuala Lumpur: Sisters in Islam

Telquel (2006) 'Avortement: Autopsie d'un Drame Social' [Abortion, Autopsy of a Social Tragedy], 18-24 February 2006

UNFPA (2006) The Gap Exists Between Hopes and Realities, New York: United Nations Population Fund

Utomo, B.; Hakim, V.; Atashendartini; Irwanto and Wirawan, D.N. (2001) 'A Report on the Incidence of Abortion in Indonesia: Result of a Communitybased Survey in 10 Major Cities and 6 Districts', presented at a Seminar on the Incidence and Social-Psychological Aspects of Abortion in Indonesia, Jakarta

WHO (2003) Safe Abortion: Technical and Policy Guidance for Health Systems, Geneva: World Health Organization

WHO (2007) Maternal Mortality in 2005, estimate developed by WHO, UNICEF, UNFPA and the World Bank, New York: World Health Organization 